\title{
Dampak Pariwisata Cagar Budaya Candhi Cetho terhadap Komunitas Agama Hindu dan Kejawen
}

\author{
Devi Muslianty \\ Center of Religious and Cross-cultural Studies \\ Of Gadjah Mada University \\ devi.muslianty@gmail.com/ 081802520881 \\ Moh. Iqbal Ahnaf \\ Center of Religious and Cross-cultural Studies \\ Of Gadjah Mada University \\ iqbalahnaf@gmail.com
}

\begin{abstract}
Does Cetho Temple need a status as a National Cultural Heritage if later it will only experience desacralization as a consequence of that status, which is then used by the government to manage the temple area as a tourist attraction? Although not recognized by the government on the grounds that there is no authentic evidence, the fact is that Cetho Temple is a place of worship not only for Hindus but also Javanese who still hold the Kejawen tradition for generations. In addition, the Cetho Temple cultural tourism tour turned out to also give rise to contestation not only between religious communities but also government institutions that oversee Cetho Temple tourism management. From all that, the commodification of religious and cultural identity is also an important impact of Cetho Temple's cultural heritage tourism on the Hindu and Kejawen Communities. The qualitative research in this paper uses the Erving Goffman theory approach on "front stage" and "back stage" to uncover the impact that temple tourism produces on religious communities which are Javanese with very polite characters and tend to be closed.
\end{abstract}

Keywords: Cetho Temple, cultural heritage, tourism, Hinduism, Kejawen, contestation

\section{Pendahuluan}

Candi Cetho adalah candi bercorak agama Hindu yang diperkirakan didirikan pada akhir abad ke 14 oleh keturunan kerajaan Majapahit yang terakhir. Candi yang terletak di Dukuh Cetho, Desa Gumeng, Kecamatan Jenawi, Kabupaten Karanganyar ini terdiri dari tiga belas bangunan berundak (bertingkat-tingkat/ teras) yang di masing-masing tingkatan tersebut diyakini oleh umat Hindu Dukuh 
Cetho sebagai bagian dari ajaran mereka tentang Tri Mandala[1]. Selain itu, pada setiap bangunan diyakini juga oleh mereka mengandung unsur-unsur kesakralan yang suci karena selain mengandung bagian dari ajaran Hindu tentang Tri Mandala, hampir di setiap bangunan terdapat arca-arca dan relief-relief yang melambangkan simbol-simbol ajaran Hindu, misalnya relief berupa Lingga Yoni yang besar di teras ke enam. Sedang bagi komunitas Kejawen mereka menganggap bahwa Candi Cetho adalah rumah nenek moyang mereka, yang menjadi pendiri Dukuh Cetho. Selain itu masa keemasan Majapahit rupanya masih menjadi cita-cita orang Jawa yang merujuk pada image ratu adil dalam legenda Jawa sehingga tempat ini populer juga sebagai tempat untuk meminta berkah kedudukan sosial yang lebih tinggi.

Komunitas Hindu dalam paper ini adalah masyarakat lokal yang sebagian besar adalah umat Hindu dan bertempat tinggal hanya beberapa langkah dari Candi Cetho. Mereka meyakini bahwa mereka sudah bertempat tinggal di sana sejak ratusan tahun bahkan ribuan tahun yang lalu. Sedangkan umat Kejawen merujuk pada umat agama lain yang masih mempraktekan ibadah tradisi Jawa di Candi Cetho dan berasal dari berbagai tempat di Karanganyar maupun kabupaten atau kota lainnya seperti Surakarta. Umat Kejawen yang menjadi sumber data dan objek penelitian diambil secara acak, tanpa menentukan komunitas Kejawen dari Padepokan tertentu, tapi orang Jawa yang datang ke Cetho untuk melakukan ritual dan juga beberapa orang yang khusus didatangi oleh penulis untuk keperluan data lainnya.

Masyarakat Hindu dan Kejawen sekitar candi mengklaim bahwa mereka sejak ratusan tahun yang lalu hingga saat ini telah menggunakan Candi Cetho sebagai tempat ibadah dan tempat suci mereka. Bahkan umat Hindu sekitar mengaku bahwaleluhur mereka ikut serta dalam perawatan Candi Cetho sejak jaman raja Brawijaya V, raja terakhir kerajaan Majapahit, yang arca dan mitologinya masih tetap terawat hingga sekarang seperti Punden Eyang Krincing Wesi, yang diakui sebagai lelehur masyarakat Dusun Cetho.Saat ini, Candi Cetho oleh penduduk Hindu sekitar dijadikansebagai Pura atau tempat ibadah umat Hindu, yang sebelum populer sebagai tempat wisata cagar budaya merupakan tempat untuk merayakan berbagai ritual keagamaan Hindu seperti Nyepi. Akan tetapi saat ini umat Hindu tidak lagi memungkinkan untuk merayakan Nyepi di candi dikarenakan keramaian pengunjung yang datang ke candi di hari Nyepi yang merupakan hari libur bagi masyarakat agama lain [2].

Di mulai pada tahun 2007, Candi Cetho sudah didaftarkan sebagai cagar budaya dan dilanjutkan pada tahun 2015 yang kembali didaftarkan sebagai cagar budaya [3]. Setelah terdaftar sebagai cagar budaya, Candi Cetho merupakan hak milik negara sebagaimana yang tercantum dalam undang-undang no. 11 tentang Cagar Budaya tahun 2010 [4]. Ditambahkan pula dalam undang-undang itu bahwa negara berhak menggunakan benda atau situs yang telah tedaftar sebagi cagar budaya tersebut untuk berbagai kepentingan misalnya penelitian, pendidikan bahkan dapat digunakan sebagai tempat wisata (lihat UU No. 11 Tahun 2010 bab VII pasal 85 ayat 2). Konsekuensi dari hal ini adalah komunitas keagamaan harus 'membagi' ruang sakralnya kepada para pengunjung yang cenderung menganggap candi adalah hanya sebagaimana tempat wisata lain yang menghibur dan siap 
untuk dinikmati sebatas lingkup materialnya saja atau bahkan untuk kasus candi Cetho yang terdapat relief lingga yoni yang serupa dengan alat organ genital manusia, Candi Cetho merupakan jejak peninggalan masa pemujaan berhala dan bukti candi yang porno.

Pada dasarnya, dengan diserahkannya sebuah situs untuk didaftarkan sebagai cagar budaya khususnyauntuk kasus Candi Cetho, negara secara tidak langsung tidak lagi mengakui eksistensi komunitas keagamaan sebagai pengguna ataupun kelompok pewaris keberlangsungan pengunaan Candi Cetho sebagaimana yang menjadi syarat sebuah situs sebagai monumen hidup atau living monument. Kemudian selanjutnya, kelompok-kelompok keagamaan tersebut harus melakukan administrasi perijinan jika hendak melakukan ibadah keagamaan mereka di candi itu. Ironisnya, walaupun dalam hal ini kemudian komunitas Hindu harus melakukan perijinan, ritual-ritual mereka ini kemudian 'dijual' oleh pemerintah lokal sebagai salah satu daya tarik pariwisata Candi Cetho untuk menjaring pengunjung sebanyak mungkin untuk datang ke Candi Cetho. Secara singkat dapat diasumsikan bahwa dalam hal ini masyarakat Hindu hanya dijadikan aktor dalam promosi pariwisata Candi Cetho bukan sebagai pemilik Candi Cetho.

Lebih jauh lagi, identitas Hindu yang digunakan oleh pihak pengelola wisata cagar budaya Candi Cetho terkesan berusaha hendak menonjolkan identitas Hindu Bali yang telah sejak beberapa tahun terakhir menjalin hubungan baik dengan pemerintah khususnya pemerintah daerah Kabupaten Karanganyar dan bahkan beberapa orang Bali memberikan perhatian lebih terhadap candi dengan cara memberikan donasi untuk keperluan perbaikan dan ritual-ritual keagamaan di Cetho.

Penelitian dalam paper ini menggunakan pendekatan kualitatif etnografi dengan menggunakan teori Goffman tentang 'panggung depan' dan 'panggung belakang' sebagai alat untuk menggungkap dampak sebenarnya dari wisata cagar budaya Candi Cetho. Area penelitian ini berlokasi di Dukuh Cetho, Desa Gumeng, Kecamatan Jenawi, Kabupaten Karanganyar, Jawa Tengah. Data dikumpulkan melalui interview dan observasi partisipan that direct involve in beberapa ritual yang diselenggarakan oleh umat Hindu. Selain itu, kajian pustaka juga diperlukan untuk mendukung beberapa data yang bersifat sejarah, legenda, ataupun mitologi. Pemilihan informan dalam penelitian ini menggunakan metode 'bola salju', dimana informan dipilih berdasarkan rekomendasi dari seseorang saat ditanyai mengenai hal atau informasi yang hendak atau sedang dicari. Penelitian dalam paper ini melakukan kajian terhadap panggung depan dan panggung belakang wisata cagar budaya Candi Cetho untuk dapat lebih menggali dampak yang ditimbulkan dari wisata cagar budaya Candi Cetho.

\section{Kajian Pustaka}

Panggung depan menurut Goffman (1959) dalamThe Presentation Self Everyday Life,adalah situasi dimana segala sesuatu terjadi atas pengaturan atau dekorasi yang hendak ditampilkan sesuai dengan keadaan atau situasi yang melatar belakanginya. Sebagai contoh saat seorang badut sedang menampilkan kesenian menghiburnya, dia harus berusaha sebaik mungkin untuk menghibur, walaupun kemungkinan untuk badut memiliki masalah berat yang membuat gundah hatinya. Sedangkan panggung belakang adalah situasi dimana segala sesuatunya terjadi 
secara alami tanpa mengharuskan menghasilkan kesan sempurna atau indah dihadapan sekelompok audiens. Sebagai contoh lainnya saat badut yang telah selesai menghibur, akan menghapus riasan wajahnya juga mengganti kostum badut dengan baju biasa yang lebih nyaman untuknya karena tidak panas dan berat. Situasi ini menampilkan situasi dimana badut sedang berada di panggung belakang; tanpa riasan, dan kostum yang berat sehingga badut dapat menjadi dirinya sendiri tanpa harus berusaha keras untuk menampilkan kesan apapun kepada siapapun. Dalam hal ini, panggung wisata cagar budaya Candi Cetho juga memiliki panggung depan dan panggung belakang yang memiliki sisi yang berbeda dalam penyajian keadaan yng terjadi.

Di panggung depannya, wisata cagar budaya Candi Cetho menghadirkan pertemuan antara agama Hindu dengan budaya masyarakat setempat, yaitu budaya Jawa. Pertemuan ini menghadirkan attraksi pariwisata yang sangat eksotis berupa ritual-ritual adat Hindu-Jawa yang diharapkan mampu meningkatkan jumlah kunjungan di Candi Cetho yang berdampak pada peningkatan jumlah pendapat pemerintah khususnya pemerintah lokal.Kesan lain yang hendak ditampilkan dalam penanganan wisata cagar budaya Candi Cetho adalah adanya kerjasama yang indah antara instansi-instansi di dalamnya. Instansi-instansi tersebut adalah departement pariwisata dan institute for Preservation of Cultural Heritage di central Java [7] dengan pembagian wilayah kerja adalah bagian perawatan candi beserta batu-batunya adalah menjadi wilayah kerjanya BPCB Jawa Tengah, dan pelayanan tiket masuk serta melakukan promosi wisata cagar budaya Candi Cetho baik melalui media cetak maupun media eteknologi.

Panggung depan lainnya adalah penampilan penduduk lokal dari latar belakang agama berbeda yang bersama-sama menjalankan proyek Kainisasi. Proyek ini adalah pelayanan penggunaan kain dalam hal ini adalah kain poleng yang merupakan kain khas umat Hindu Bali, kepada pengunjung yang hendak masuk ke area Candi Cetho. Pengunjung diberi kebebasan dalam memberikan uang terhadap 'sewa' kain yang dikenakan. Proyek ini adalah proyek yang diklaim sebagai proyek yang dicetuskan idenya pertama kali adalah dari Peradah sebagai organisasi pemuda Hindu Desa Gumeng [8]. Di awal berdirinya, proyek ini memang hanya melibatkan kalangan pemuda Hindu saja, dan semua hasil keuntungan dari projek kainisasi ini adalah diberikan dan digunakan kepada organisasi pemuda Hindu Desa Gumeng.Akan tetapi di waktu selanjutnya, proyek ini dilakukan bersama-sama seluruh pemudah dari karang taruna desa Gumeng dari latar belakang agama yang berbeda, dan diklaim sebagai proyek lintas agama pemuda Desa Gumeng.

Panggung belakang sebagai potret realita keadaan masyarakat Hindu dan Kejawen di Candi Cetho di capture melalui berbagai pendekatan informal, seperti misalnya berbaur ikut serta dalam upacara-upacara yang dilaksanakan, makan di warung bersama, tidak menggunakan bahasa-bahasa yang ilmiah atau pun akademis, dan membangun hubungan nyaman dan saling percaya di antara penulis dengan warga masyarakat setempat dan juga pengunjung dari Kejawen yang datang ke Candi Cetho untuk beribadah. Pendekatan ini dilakukan dalam waktu yang relatif panjang dan intensif. 
Walaupun tidak secara langsung dan frontal, kehadiran masyakarat Bali di awal kebangkitan pariwisata cagar budaya Candi Cetho adalah sesuatu yang sedikit banyak membawa perubahan pada sisi tatanan ritual yang dilakukan masyarakat Hindu Dukuh Cetho, seperti halnya perayaan Galungan yang sekarang telah juga dirayakan oleh masyarakat Hindu Jawa khususnya di Candi Cetho. Selain itu, ornamen-ornamen keBalian juga sedikit banyak terlihat di Candi Cetho, seperti halnya penggunaan kain poleng di proyek kainisasi, penggunaan candi bentar Bali di rumah-rumah penduduk lokal, hingga praktek tatanan ritual, hingga sesaji yang bernuansa Bali mulai muncul. Hal ini diungkapkan oleh penduduk lokal berawal dari kebangkitan pariwisata Candi Cetho sekitar tahun 2004-2010, dimana banyak orang Bali memberikan dukungan berupa dana untuk perhelatan sebuah ritual, hingga membantu untuk mempercantik bangunan di Candi Cetho sebagai bentuk wujud yang diyakini oleh orang Bali sebagai ngayah di Pura. Selain itu, warga Bali juga tidak sedikit yang menyumbangkan sesaji yang menurut warga lokal kurang cocok bagi mereka untuk diterapkan di wilayah Jawa, misalnya penggunaan daun kelapa muda (janur), canang, sebagai wadah sesaji, karena agak sedikit sulit untuk mendapatkannya di wilayah Jawa khususnya di daerah sekitar Candi Cetho, dan keadaan sesaji yang dibawa langsung dari Bali biasanya sudah dalam kondisi tidak segar untuk disajikan kepada dewa-dewa atau leluhur di Candi Cetho.

Proyek kainisasi yang dinyatakan sebagai proyek pemuda lintas agama Dukuh Cetho bukan tanpa perdebatan dan konflik. Berdasarkan wawancara dengan pemuda lokal, didapatkan informasi bahwa keikutsertaan pemuda Dukuh Cetho dari agama lain adalah berawal dari protes yang dilakukan pemuda dari agama lain terkait hasil dari kainisasi yang hanya diperuntukkan bagi kas pemuda Hindu saja, dan hanya melibatkan pemuda Hindu saja. Sehingga diskusi untuk mendapatkan jalan keluar dari masalah ini menghasilkan mekanisme proyek kainisasi yang baru, yaitu pembagian keuntungan dari kainisasi akan dibagi untuk Peradah Dukuh Cetho, lalu Karang Taruna Dukuh Cetho dan sisanya juga diberikan untuk kas desa. Pemuda dari agama lainnya kemudian dilibatkan untuk melayani pengunjung dalam penggunaan kain ketika akan masuk ke Candi Cetho. Kerjasama yang ditampilkan antara BPCB Jawa Tengah dengan Dinas Pariwisata Karanganyar dalam hal managemen Wisata Cagar Budaya Candi Cetho di panggung depan bukan tanpa hambatan di belakang panggung. Dinas Pariwisata Kabupaten Karanganyar yang sebelumnya tidak terlibat dalam pengelolaan Candi Cetho, merasa memiliki Candi Cetho sebagai aset pemerintah Karanganyar yang potensial untuk dimanfaatkan segi pariwisatanya dalam rangka untuk meningkatkan pendapatan daerah Kabupaten Karanganyar. Dinas ini diinformasikan oleh penduduk lokal yang merupakan pemimpin keagamaan umat Hindu dan didukung dengan pernyataan dari staf BPCB Jawa Tengah yang mengatakan bahwa sempat terjadi hubungan yang memanas di antara dinas-dinas ini, bahkan Dinas Pariwisata melakukan demo dengan menghadang pejabat BPCB yang hendak ke Candi Cetho. Mereka menuntut untuk diadakan 'cost sharing' atau bagi hasil yang sama rata yaitu lima puluh persen-lima puluh persen untuk mereka masing-masing dari keuntungan tiket masuk pengunjung Candi Cetho. Dinas Pariwisata mengklaim bahwa mereka telah melakukan promosi yang besar 
untuk meningkatkan pariwisata Candi Cetho hingga sekarang bisa memiliki kenaikan jumlah pengunjung yang banyak. Tuntutan ini diajukan karena dalam kebijakan sebelumnya pihak Dinas Pariwisata hanya memperoleh sebagian kecil dari keuntungan tiket masuk pengunjung Candi Cetho.

Isu lain yang penelitian ini mampu ungkapkan adalah isu tentang tidak diakuinya eksistensi komunitas keagamaan yang melakukan ritual keagamaan di Candi Cetho. Sehingga mereka harus mengajukan ijin terkait penyelenggaraan kegiatan keagamaan tersebut setiap tahunnya. Padahal dalam agenda wisata sebagai daya tarik wisata Candi Cetho, ritual, khususnya yang bersifat agenda tahunan seperti misalnya Nyepi dan Galungan tetap dilakukan. Secara sederhana, hal ini seperti pemanfaatan warga lokal dan juga ritual-ritual keagamaannya hanya sebagai daya tarik wisata semata. Di sisi lain perubahan kegiatan keagamaan yang dulu dapat dilakukan di Candi Cetho harus mengalah dari tuntutan pariwisata, seperti halnya kegiatan Nyepi yang sudah jarang dilakukan di Candi karena candi buka pada hari libur Nyepi.

Keberadaan warga Kejawen sebagai orang Jawa yang masih terus mempraktekkan budaya Jawa termasuk bersembahyang di Candi Cetho. Jika pada waktu sebelumnya orang Kejawen dapat melaksanakan ritual keagamaannya, misalnya bersemedi, pada pagi hari, akan tetapi sekarang ini mereka tidak bisa secara leluasa melakukan ritual keagamaan mereka karena banyak pengunjung di Candi Cetho. Untuk itu mereka sekarang melakukan kegiatan keagamaan mereka dari sore hingga tengah malam bahkkan hingga dini hari. Terlepas dari jadwal ritual keagamaan yang berubah, mereka juga harus mengalami ritual adat kejawen dengan tata cara persembahyangan yang merujuk pada tata ritual Hindu, yang agak sedikit berbeda dengan ritual asli kejawen.

\section{Pembahasan}

Penelitian dari panggung depan dan panggung belakang wisata cagar budaya Candi Cetho dalam paper ini, menghasilkan beberapa temuan atas pertanyaan apa dampak wisata cagar budaya, dan berusaha membingkainya dalam pemahaman analisis atas apa yang terjadi. Hasil kajian dalam paper ini menemukan bahwa wisata cagar budaya menghasilkan beberapa temuan antara lain, kontestasi, dan komodifikasi agama dan budaya. Kontestasi yang terjadi dibagi menjadi dua yaitu berdasarkan perbedaan pemaknaan atas candi dan alasan klasik yaitu ekonomi. Kontestasi tersebut terjadi tidak hanya antara komunitas keagamaan tetapi juga komunitas keagamaan dengan pemerintah dan antar instansi pemerintah itu sendiri.

Perbedaan pemaknaan yang terjadi antara pemerintah, pengunjung Candi Cetho, serta komunitas keagamaan, dibingkai sebagai salah satu dari bentuk kontestasi. Pemerintah yang dalam hal ini diwakili oleh Dinas Pariwisata Kabupaten Karanganyar dan BPCB Jawa Tengah, menganggap Candi Cetho hanya objek atau benda yang tidak memiliki nilai atau makna keagamaan apapun selain kemungkinan akan kandungan jejak sejarah dan budaya masyarakat Jawa di masa lalu. Karena menurut UU No. 11 tentang Cagar Budaya tahun 2010 Bab VI bagian kedua, saat sebuah situ terdaftar sebagai cagar budaya dan diambil alih oleh pemerintah maka secara tidak langsung bahwa benda atau situs tersebut dinyatakan tanpa pemilik atau pewaris sejarah dan tidak memiliki 
keberlangsungan fungsi lagi, hingga memungkinkan untuk digunakan untuk berbagai tujuan termasuk sebagai objek wisata oleh pemerintah.Konsekuensi dari hal ini adalah pembagian ruang sakral Candi Cetho terhadap pengunjung Candi Cetho yang sebagian besar tidak memaknai Candi Cetho sebagai ruang atau bangunan sakral, sehingga mereka menganggap bagian-bagian candi hanya sebagai objek wisata yang bisa diduduki arcanya, bisa ditulisi dinding candinya dan berbagai kegiatan yang mengarah pada tindakkan desakralisasi lainnya.

Komunitas keagamaan yaitu komunitas Hindu dan Kejawen adalah komunitas yang menerima dampak langsung dari penggunaan Candi Cetho sebagai objek wisata. Selain desakralisasi atas objek sakral mereka, khusus komunitas Kejawen, mereka harus bernegosiasi bahkan mengakomodir nilai-nilai Hindu yang diproyeksikan identik dengan Bali dalam ritual adat Jawa yang masih dilaksanakan di Candi Cetho.Sebagai contoh kegiatan ritual Mondosiyo yang mengandung lebih banyak unsur Hindu, dari pemimpin ibadah yang dilibatkan hingga tatanan ritual dan sesaji yang digunakan. Selain itu jadwal praktek keagamaan seperti tapa brata, sekarang sebagian besar harus dilakukan pada sore menjelang malam hingga dini hari untuk menghindari keramaian yang diakibatkan dari kedatangan pengunjung Candi Cetho.

Faktanya kontestasi tidak hanya terjadi terhadap komunitas keagamaan semata, akan tetapi juga antar instansi pemerintahan sebagai lembaga yang mengelola kelestarian, perawatan, hingga pengelolaan pariwisata Candi Cetho. Salah satu motif yang bisa diasumsikan muncul sebagai penyebab dari kontestasi tersebut adalah motif ekonomi. Hal ini dapat disimpulkan dari perdebatan tentang pembagian hasil keuntungn dari tiket masuk pariwisata Candi Cetho yang dituntut oleh Dinas Pariwisata Kabupaten Karanganyar untuk dibagi rata antar BPCB Jawa Tengah dengan Dinas Pariwisata. Hingga berujung pada demo dan penghadangan orang-orang dari BPCB oleh orang yang diyakini dari pihak Dinas Pariwisata. Penyelesaian dari permasalahan ini akhirnya dengan perjanjian pembagian rata keuntungan dari tiket masuk wisata Candi Cetho.

Kontestasi antar instansi pemerintah bukan satu-satunya perdebatan dengan motif ekonomi. Kejadian yang terjadi di kainisasi juga dapat disimpulkan sebagai bagian dari motif ekonomi. Kesimpulan diambil dari penggambaran kejadian yang terjadi karena tuntutan dari sekelompok orang untuk membagi hasil dari keuntungan donasi penggunaan kain dari pengunjung Candi Cetho. Hingga akhirnya, pembagian keuntungan yang sebelumnya utuh diberikan kepada organisasi pemuda Hindu, dibagi kepada Karang Taruna dan organisasi kemasyarakatan lainnya.

\section{Komodifikasi Identitas}

Selain kontestasi, penelitian dalam paper ini juga menemukan adanya komodifikasi identitas agama dan budaya sebagai akibat dijadikannya Candi Cetho sebagai wisata cagar budaya. Isu komodifikasi dipakai dalam hal ini untuk menggambarkan situasi yang terjadi terhadap komunitas keagamaan Hindu dan Kejawen yang menampilkan ritual keagamaan mereka di Candi Cetho sebagai tempat yang diyakini sakral oleh mereka akan tetapi di sisi lain tempat tersebut dianggap hanya sebagai monumen peninggalan yang mengandung unsur sejarah dan budaya Jawa tanpa embel-embel nilai keagamaan sedikitpun di dalamnya. 
Komunitas keagamaan yang melakukan ritual keagamaan dan budaya di candi kemudian diakomodir untuk dijadikan daya tarik pariwisata semata dengan mengharuskan mereka melakukan ijin atas penampilan ritual keagamaan tersebut. Tuntutan atas pengakuan sebagai pura atau tempat ibadah umat Hindu hingga ritual dilakukan tanpa harus meminta ijin, menjadi sesuatu yang hampir tidak mungkin diberikan oleh pemerintah dalam hal ini adalah BPCB Jawa Tengah. Hal menarik sebagai temuan dalam penelitian ini adalah jika BPCB Jawa Tengah dengan tegas menyatakan bahwa Candi Cetho adalah hanya monumen peninggalan yang sudah ditinggalkan atau dead monument, sehingga mereka pun tidak akan mengakui Candi Cetho sebagai Pura atau tempat ibadah umat Hindu [14]. Pernyataan agak berbeda akan ditemukan dari Dinas Pariwisata Kabupaten Karanganyar, walau mereka tidak mengakui Candi Cetho sebagai monumen yang terus terjaga keberlangsungan fungsi dan perawatannya (living monument), tapi mereka mengakui bahwa Candi Cetho sebagai Pura. Hal ini diasumsikan penulis sebagai upaya yang dilakukan untuk terus menjaga keberlangsungan ritual keagamaan dan adat di Candi Cetho yang telah dijadikan sebagai daya tarik wisata Candi Cetho.

\section{Simpulan}

Penggunaan Candi Cetho sebagai objek wisata cagar budaya berdampak terhadap komunitas keagamaan Hindu dan Kejawen sebagai komunitas yang telah beribadah di candi sejak ratusan bahkan ribuan tahun yang lalu dari generasi ke generasi. Dampak yang terlihat nyata yang dapat dibingkai di penelitian dalam paper ini adalah kontestasi dan komodifikasi identitas agama dan budaya. Tulisan ini menyimpulkan bahwa dampak tersebut muncul dari multi komponen yaitu terdaftarnya Candi Cetho sebagai cagar budaya nasional, dan kemudian dijadikan sebagai objek wisata cagar budaya.

\section{Daftar Pustaka}

BPCB website, https://cagarbudaya.kemendikbud.go.id>, diakses pada 3 Mei 2018.

Eliade, Mircea. 1968. The Sacred and The Profane. New York: A Harverst Book Harcourt, Brace \& World, Inc.

Goffman, Erving. 1956. The Presentation of Self in Everyday Life. Universitas of Edinburgh Social Sciences Research Centre.

Hidayati, Siti Nurul. 2006. Oprimalisasi Situs Candi Sukuh dan Candi Cetho dalam Pengembangan Pariwisata.

Sheperd, Robert. 2002. Commodification, Culture and Tourism.New Delhi: Sage Publication. 